\title{
EFFECT OF NITROGEN FIXING BACTERIA AND NITROGEN RATE ON YIELD AND GROWTH OF COMMON BEAN
}

\author{
Somaye Fallahi ${ }^{1}$, Peyman Sharifi ${ }^{1}$ \\ ${ }^{1}$ Department of Agronomy and Plant Breeding, Rasht Branch, Islamic Azad University, Rasht, Iran \\ Link to this article: https://doi.org/10.11118/actaun202068030491 \\ Received: 4. 3. 2019, Accepted: 8. 6. 2020
}

To cite this article: FALLAHI SOMAYE, SHARIFI PEYMAN. 2020. Effect of Nitrogen Fixing Bacteria and Nitrogen Rate on Yield and Growth of Common Bean. Acta Universitatis Agriculturae et Silviculturae Mendelianae Brunensis, 68(3): 491-496.

\begin{abstract}
To study the effects of nitrogen $(\mathrm{N})$ rate and co-inoculation of nitrogen-fixing bacteria (Rhizobium phaseoli) on common bean, an experiment was performed in Rasht, Iran. Common bean genotype, Guilanian landrace, was planted in a factorial experiment based on a randomized complete block design with three replicates on April, $15^{\text {th }}$ in 2014. The first and second factors were nitrogen rates (0, 30, 60, 90 and $120 \mathrm{~kg} \cdot \mathrm{ha}^{-1}$ as urea) and Rhizobium phaseoli (inoculation and un-inoculation), respectively. Nitrogen had significant effect on seed yield and plant height. The effect of Rhizobium phaseoli was significant on seed yield, plant height, pod length, pods per plant, seeds per pod and nitrogen content in leaf. Interaction effects of nitrogen and Rhizobium phaseoli were not significant on any of the traits. Application of $60 \mathrm{~kg} \cdot \mathrm{ha}^{-1}$ nitrogen significantly improved seed yield, plant height and number of pods per plant. Nitrogen supply beyond the $60 \mathrm{~kg}^{-h a^{-1}}$ decreased plant height, pods per plant and seed yield. The greatest values of seed yield $\left(1635 \mathrm{~kg}^{-12-1}\right)$, plant height $(30.01 \mathrm{~cm})$, pod length (13.19 cm), number of pods per plant (6.7), number of seeds per pod (4.34) and nitrogen content in leaf (4.12\%) was observed in inoculation treatment. The results indicated the inoculation of common bean seeds by Rhizobium phaseoli improved the plant growth, productivity and quality. Therefore, the common bean inoculation with Rhizobium phaseoli is suitable to achieve the yield potential and reduce the adverse effects of environmental and may be recommended due to its advantages in terms of reduced application of nitrogen fertilizer.
\end{abstract}

Keywords: Phaseolus vuigaris, protected agriculture, Rhizobium phaseoli, mineral, yield

\section{INTRODUCTION}

Common bean (Phaseolus vuigaris L.) are as a perfect food because of its generous amounts of fiber and high protein content, complex carbohydrates and other nutritional needs including folic acid, iron, copper, potassium and zinc. Beans complement other food crops like maize and rice which are primary sources of carbohydrates (Xu and Chang, 2008).

Nitrogen $(\mathrm{N})$ is recognizing a major constraint to crop production and require by plants in comparatively larger amounts than other elements
(Habete and Buraka, 2016). Beans use inorganic soil nitrogen or applied fertilizer nitrogen and $\mathrm{N}_{2}$ fixed by a symbiotic relationship with Rhizobium phaseoli. The nitrogen fixing bacteria have ability to improve the growth and yield of plants by fixing the atmospheric nitrogen and play an important role to overcome this problem. Although the association legume plants with Rhizobium bacteria provides a part of the nitrogen, but the amount supplied is not adequate for the nitrogen necessary of crop. Bean plants with deficient in nitrogen show lower development and grain yield (Oliveira et al., 1996). 
Bacteria from Rhizobium genera are fixing nitrogen symbiotically in a specific organ called as nodule (Dixon and Kahn, 2004). It is necessary the inorganic and symbiotic nitrogen sources for highest seed yield of legumes; however, as the increases soil nitrogen or fertilizer nitrogen can lead to decreases the fixing of nitrogen by the symbiosis bacteria (Gicharu et al., 2013). Rhizobium inoculation increased shoot and root dry weight, yield components and photosynthetic pigments in bean and most of the legumes (Lamptey et al., 2014). Unquestionably, nitrogen fertilizers at different sources with low quantities are important for increasing yield and growth of legumes as well as chlorophyll and carotenoids content in leaves (Daur et al., 2008). A relatively low amount of available $\mathrm{N}$ during the initial plant development generally increases nodulation and plant growth (Aslam et al., 2010).

Several studies have tried to discover the effects of Rhizobia strains to cope the nitrogen requirements of bean (Stajkovic et al., 2011; Vargas et al., 2000; Habete and Buraka, 2016). Unfortunately, biological nitrogen fixation in common bean field crops has exhibited unstable behavior (Soares et al. 2006). Some of studies indicated beans respond to nitrogen fertilization (Soratto et al., 2010; Salehin and Rahman, 2012; Abdzad Gohari and Amiri, 2010). This indicates that their symbiotic $N_{2}$ fixation process generally does not offer sufficient $\mathrm{N}$ for most yields. Bozorgi et al. (2011) indicated significant effects of nitrogen on seed yield, biological yield, harvest index, plant height, 100 seed weight, pods per plant and seeds per pod in faba bean.

The main purpose of present study was to assess the effects of nitrogen fertilizer rate and nitrogen fixing bacteria (Rhizobium phaseoli L.) on growth and yield of common bean.

\section{MATERIALS AND METHODS}

A field experiments carried out during the spring of 2014 at the experimental farm (longitude, $49^{\circ} 38^{\prime} \mathrm{E}$; latitude, $37^{\circ} 12^{\prime} \mathrm{N}$ and altitude, $7 \mathrm{~m}$ below the mean sea level) in Rasht, Guilan, Iran, to study the effect of nitrogen fertilization rate and nitrogen fixing bacteria (Rhizobium phaseoli L.) on yield and growth of common bean. The soil chemical properties before the start of the experiment are presented in Tab. I.

The treatment combinations were randomly arranged in a factorial design based on randomized complete block design with three replicates. The first factor was containing five nitrogen rates $(0,30$,
60, 90 and $120 \mathrm{~kg} \cdot \mathrm{ha}^{-1}$ as urea) and the second factor was Rhizobium treatment including (inoculation and un-inoculation with Rhizobium phaseoli). To inoculate the seeds with $\mathrm{N}$ fixing bacteria (Rhizobium phaseoli) bacteria, the seeds were first disinfected in $2 \%$ sodium hypochlorite solution for three minutes and then rinsed five times with distilled water. For further adhesion, before inoculation, the seeds were impregnated with water and sugar solution and then inoculated at a rate of $7 \mathrm{ml} . \mathrm{kg}^{-1}$. They were kept in the shade for two hours and immediately cultured. (Alikhani et al., 2006). The nitrogen rates were applied, using urea, 20 days after seedling emergence between rows.

This experiment was conducted on field and the genotype used was a common landrace of bean (Phaseolus vuigaris L.) in Guilan province, which is widely planted in this area of northern Iran. Inoculated and un-inoculated seeds were planted on $15^{\text {th }}$ April. Basal fertilizers were used at the rates of $31 \mathrm{~kg} \cdot \mathrm{ha}^{-1} \mathrm{P}$ and $50 \mathrm{~kg} \cdot \mathrm{ha}^{-1} \mathrm{~K}$, as triple superphosphate and potassium sulfate, respectively. All of the phosphorus and potassium fertilizers were used when of last land preparing stage.

The common bean was planted at the rate of 22 plants $\mathrm{m}^{-2}(30 \times 15 \mathrm{~cm}$ spacing distance). All the seeds were sown in plots of $3 \times 4 \mathrm{~m}$ in dimensions. Weeds were removed by hand and plots were irrigated as required through the growing seasons. Plants were harvested by hand, when pods matured in June. Ten mature plants were randomly sampled from each plot and evaluated for the number of pods per plant, number of seeds per pod, plant height, pod length and 100 seed weight. Seed yield were measured in six meter square area of each plot. The leaves were dried at a temperature of $75^{\circ} \mathrm{C}$ for $48 \mathrm{~h}$ in an Owen and then total nitrogen content of samples was measured by the Kjeldahl method (Kjeldahl, 1883).

Statistical analysis was performed using SAS, version 9.1 (SAS Institute, Cary, NC). Means were compared using LSD (least significant differences) test at 5\% probability level.

\section{RESULTS}

The effect of nitrogen rate was significant only on seed yield and plant height. The effect of Rhizobium phaseoli was significant on seed yield, plant height, pod length, pods per plant, seeds per pod and leaf $\mathrm{N}$ content. Interaction effects of nitrogen and Rhizobium phaseoli were not significant on any of traits (Tab. II).

I: Some of soil characteristics in experimental field

\begin{tabular}{cccccc}
\hline Sand (\%) & Clay (\%) & Loam (\%) & Acidity or PH & Electrical conductivity (dS.m $\left.{ }^{-1}\right)$ \\
\hline 37.5 & 23 & 39.5 & 6.01 & 0.41 \\
\hline Absorbable potassium (ppm) & Absorbable phosphorus (ppm) & Nitrogen (\%) & Carbon (\%) & Tissue \\
\hline 200 & 7.78 & 0.08 & 0.94 & Loam \\
\hline
\end{tabular}


II: Analysis of variance for yield and yield components

\begin{tabular}{|c|c|c|c|c|c|c|c|c|c|}
\hline \multirow{2}{*}{ SOV } & \multirow{2}{*}{$\mathrm{df}$} & \multicolumn{8}{|c|}{ Mean Square } \\
\hline & & SY & HSW & $\mathrm{PH}$ & NPP & NSP & $\mathrm{PL}$ & SN & LN \\
\hline $\mathrm{R}$ & 2 & 43093.9 & 5.83 & 4.85 & 0.03 & 0.26 & 0.79 & 0.019 & $1.12^{* *}$ \\
\hline $\mathrm{N}$ & 4 & $167038.4^{* *}$ & 39.58 & $30.53^{* *}$ & 0.58 & 0.43 & 0.24 & 0.077 & 0.12 \\
\hline $\mathrm{Ri}$ & 1 & $448229.6^{* *}$ & 40.83 & $109.44^{* *}$ & $1.32^{* *}$ & $1.16^{* *}$ & $3.67^{* *}$ & 0.031 & $1.03^{*}$ \\
\hline $\mathrm{N}^{*} \mathrm{Ri}$ & 4 & 4990.8 & 9.58 & 7.98 & 0.10 & 0.06 & 0.18 & 0.029 & 0.10 \\
\hline Error & 18 & 10979.64 & 16.94 & 3.05 & 0.28 & 0.18 & 0.37 & 0.025 & 0.104 \\
\hline $\mathrm{CV}$ & & 6.92 & 10.08 & 6.22 & 8.19 & 10.25 & 4.73 & 4.99 & 8.28 \\
\hline
\end{tabular}

*,* significant at $5 \%$ and $1 \%$ probability levels, respectively

N: nitrogen fertilizers, Ri: Rhizobium phaseoli, PH: plant height, PL: pod length, NPP: number of pods per plant, NSP: number of seeds per pod, SY: seed yield, HSW: hundred seed weight, SN: Nitrogen content in seed, LN: Nitrogen content in leaf, CV: Coefficient of variation

\section{Effect of Rhizobium Inoculation}

It is obvious from Tab. III that seed inoculation of common bean with Rhizobium phaseoli significantly increased the studied traits. The greatest values of seed yield (1635 kg.ha-1), plant height $(30.01 \mathrm{~cm})$, pod length $(13.19 \mathrm{~cm})$, pods per plant (6.7), seeds per pod (4.34) and nitrogen content in leaf (4.12\%) were recorded when seeds inoculated with nitrogen fixing bacteria (Rhizobium phaseoli L.). Seed yield, plant height, pod length, pods per plant, seeds per pod and nitrogen content in leaf were increased by $17.63,14.60,11,5.6$ and $11.26 \%$, respectively due to Rhizobium phaseoli inoculation.

\section{Effect of Nitrogen Fertilization}

For the treatments with $60 \mathrm{~kg} \cdot \mathrm{ha}^{-1}$ nitrogen, seed yield was higher than in the treatments with no $\mathrm{N}$, even with the application of other amounts of $\mathrm{N}$ (Tab. IV). There was not significant difference between rates of 30, 90 and $120 \mathrm{~kg} \cdot \mathrm{ha}^{-1}$ nitrogen. This emphasizes the importance of nitrogen fertilization in bean crop. With the application of 90 and $120 \mathrm{~kg} \cdot \mathrm{ha}^{-1}$ nitrogen, plant height was lower than the application of 30 and $60 \mathrm{~kg}^{-h a^{-1}} \mathrm{~N}$. Nitrogen supplied at the rate of $60 \mathrm{~kg}^{-h^{-1}}$ resulted in higher number of pods per plant. There were not significant differences between 0, 30, 90 and $120 \mathrm{~kg} . \mathrm{ha}^{-1}$ nitrogen. These results indicated that applying nitrogen at the rate of $60 \mathrm{~kg} \cdot \mathrm{ha}^{-1}$ might be the optimum rate to cause a desirable increase in plant height and number of pods per plant. Therefore, further increase in nitrogen up to $60 \mathrm{~kg} \cdot \mathrm{ha}^{-1}$ has a negative effect on plant height and number of pods per plant.

III: The effect of Rhizobium phaseoli on yield and yield components of bean

\begin{tabular}{lcccccc}
\hline Rhizobium phaseoli & SY $\left(\mathrm{kg}^{-h \mathrm{~h}^{-1}}\right)$ & PH (cm) & NPP & NSP & PL (cm) & LN(\%) \\
\hline Inoculate & $1635^{\mathrm{a}}$ & $30.01^{\mathrm{a}}$ & $6.7^{\mathrm{a}}$ & $4.34^{\mathrm{a}}$ & $13.19^{\mathrm{a}}$ & $4.12^{\mathrm{a}}$ \\
UnInoculate & $1390^{\mathrm{b}}$ & $26.19^{\mathrm{b}}$ & $6.3^{\mathrm{b}}$ & $3.91^{\mathrm{b}}$ & $12.49^{\mathrm{b}}$ & $3.67^{\mathrm{b}}$ \\
LSD (5\%) & 80.38 & 1.34 & 0.41 & 0.32 & 0.46 & 0.32 \\
\hline
\end{tabular}

PH: plant height, PL: pod length, NPP: number of pods per plant, NSP: number of seeds per pod, SY: seed yield, LN: Nitrogen content in leaf, LSD: least significant differences

Common letters in a column indicate no significant difference $(\mathrm{P}<.05)$

IV: The effect of nitrogen fertilization on yield and yield components of bean

\begin{tabular}{cccc}
\hline Nitrogen $\left(\mathrm{kg}^{-h \mathrm{~h}^{-1}}\right)$ & SY $\left(\mathrm{kg} \cdot \mathrm{ha}^{-1}\right)$ & PH (cm) & NPP \\
\hline 0 & $1285^{\mathrm{c}}$ & $27.97^{\mathrm{b}}$ & $6.2^{\mathrm{b}}$ \\
30 & $1472^{\mathrm{b}}$ & $30.33^{\mathrm{a}}$ & $6.7^{\mathrm{ab}}$ \\
60 & $1750^{\mathrm{a}}$ & $30.4^{\mathrm{a}}$ & $6.9^{\mathrm{a}}$ \\
90 & $1550^{\mathrm{b}}$ & $26.33^{\mathrm{bc}}$ & $6.4^{\mathrm{ab}}$ \\
120 & $1480^{\mathrm{b}}$ & $25.43^{\mathrm{c}}$ & $6.2^{\mathrm{b}}$ \\
LSD (5\%) & 127.1 & 2.12 & 0.64 \\
\hline
\end{tabular}

SY: seed yield, PH: plant height, LSD: least significant differences

Common letters in a column indicate no significant difference $(\mathrm{P}<.05)$ 


\section{DISCUSSION}

Results indicated seed inoculation of common bean with Rhizobium phaseoli significantly increased seed yield, plant height, pod length, pods per plant, seeds per pod and nitrogen content in leaf. In agreement the results of present study, Ronner et al. (2016) revealed Rhizobium inoculants improve the availability of soybean seed yield. Ahmadi-Rad et al. (2016) indicated foliar application of bacteria (Azotobacter and Azospirillum) significantly increased the yield and growth of canola. Gicharu and Gitonga (2013) were also indicated the inoculation of climbing common bean increased the nodules formation and seed yield in comparison to control. Bacem et al. (2007) stated common bean is as an inefficient N-fixation crop as compared with other legumes. However, co-inoculation with Rhizobium had higher nitrogenase activity, leghemoglobin concentrations and atmospheric nitrogen fixation efficiency and thereby formed associations of greater symbiotic efficiency. Inoculation with Rhizobium stimulated nodulation and N fixation (Figueiredo et al., 2007). Martins et al. (2003) stated co-inoculation of Rhizobium significantly affected the nitrogenase activity in common bean root nodules. Otieno et al. (2009) were also reported the increases of food legumes yield with use of bacteria inoculation. Uyanöz and Karaca (2011) indicated inoculation with Rhizobium tropici is important to decrease the soil salinity and to make better the yield of bean. The favorable effects of bacterial inoculation on yield were also reported in the other leguminous crops (Lamptey et al., 2014; Tairo and Ndakidemi, 2013; Aslam et al., 2010). The positive effects of Rhizobium phaseoli inoculation on these traits means that rhizobia bacteria were effective in fixing nitrogen and shows that there is a possibility for mineral nitrogen partially replaced by biological nitrogen. These effects of Rhizobium phaseoli on yield and the other traits were related to the symbiotic relationship between bacteria and bean plants, that arises from fixation of $\mathrm{N}_{2}$ to roots and translocation of amino acids to the shoots, which lead to increases the seed yield (John Ndlovu, 2015). The other reason of Rhizobium can be because of the effect of these bacteria on phosphorus availability. Rhizobium makes the insoluble form of phosphorus to soluble forms and makes phosphorus available to the plant. These bacteria can live together with legumes and non legumes plants and enhance the uptake of nutrient and improve the structure of soil (Oufdou et al., 2016). Rhizobial inoculation prepared the application P-fertilizer economically interesting unlike the use of $\mathrm{P}$ alone and it is an inexpensive way to increase seed yields with low financial risks and reduce the environmental adverse (Ronner et al., 2016).

The results were also indicated application of $60 \mathrm{~kg} \cdot \mathrm{ha}^{-1}$ nitrogen had significantly improved seed yield, number of pods per plant and plant height. Similar results were reported by Geetha and Varughese (2001). The results indicated that the bean crop requires $\mathrm{N}$ for its initial growth (Soratto et al., 2010). The positive and significant effect of nitrogen fertilization on seed yield, seed weight, number of pods per plant and number of seeds per plant were also reported by Abdzad Gohari and Amiri (2010). Soratto et al. (2010) indicated even with the application of $60 \mathrm{~kg} \cdot \mathrm{ha}^{-1}$ nitrogen at planting, common bean yield was increased. This result may be due to the important role of nitrogen in structure of amino acid, protein, enzymes and chlorophyll molecule and its vital importance for plant growth (Otieno et al., 2009). The reason of reduction in number of pods per plant, plant height and seed yield with increase the amount of nitrogen is according to that the excessive available $\mathrm{N}$ can result in reduced and delayed yield and reduced dry matter content (Salehin and Rahman, 2012). Oliveira et al. (1996) were also indicated lower development and seed yield of bean plants with deficient in nitrogen. Evans et al. (2001) stated that $\mathrm{N}$ accumulations from legume crops varied from 45-225 kg.ha-1 nitrogen. It is necessary the inorganic and symbiotic nitrogen sources for greatest yields of seed legumes (Gicharu et al., 2013). Application of nitrogen fertilizer is useful for yield and growth of bean. Because the first added nitrogen is utilized for nodule growth, early growth of bean is excited by use of mineral nitrogen fertilizer. The use efficiency of nitrogen mineral fertilizer is less than 50\%, because of lost through run-off water and leaching and leading to higher production costs substantial environmental contamination. Therefore, the utilization of legumes with high ability to atmospheric nitrogen fixation and improvement the fixation of $\mathrm{N}_{2}$ by bacteria (Habete and Buraka, 2016) can be resolve the high use of nitrogen mineral fertilizer.

\section{CONCLUSION}

Application of $60 \mathrm{~kg} \cdot \mathrm{ha}^{-1}$ nitrogen had significantly improved seed yield, plant height and the number of pods per plant. Nitrogen supply beyond the $60 \mathrm{~kg} \cdot \mathrm{ha}^{-1}$ generally resulted in decline plant height, pods per plant and seed yield. It can also concluded from the results of present study that inoculation of seeds with Rhizobium significantly increased growth and yield of common bean. The higher yields achieved with Rhizobium inoculation revealed this technology is effective in supplying nitrogen to legumes as mineral nitrogen fertilizer and it is a cost-effective for resource-poor farmers. 


\section{REFERENCES}

ABDZAD GOHARI, A. and AMIRI, E. 2010. Increase of bean production in iron and nitrogen fertilization in sustainable agriculture. In: First National Congress of Sustainable Agriculture and Health Crop Production. Isfahan, pp. 230-236.

AHMADI-RAD, S., GHOLAMHOSEINI, M., GHALAVAND, A., ASGHARZADEH, A. and DOLATABADIAN, A. 2016. Foliar application of nitrogen fixing bacteria increases growth and yield of canola grown under different nitrogen regimes. Rhizosphere, 2: 34-37.

ALIKHANI, H. A., SALEH-RASTIN, N. and ANTOUM, H. 2006. Phosphate solubilizing activity of rhizobia native to Iranian soils. Plant and Soil, 287: 35-41.

ASLAM, M., AHMAD, H. K., TULLAH, H., AYAZ, M., AHMAD, E., SAGOO, A. G., ULLAH, I., HUSSAIN, A. and MANZOOR. M. 2010. Nodulation, grain yield and grain protein contents as affected by rhizobium inoculation and fertilizer placement in chickpea cultivar bittle-98. Sarhad Journal of Agriculture, 26(4): 467-474.

BACEM, M., AOUANI, M. E. and MHAMDI, R. 2007. Nodulation and growth of common bean (Phaseolus vulgaris) under water deficiency. Soil Biology and Biochemistry, 39(7): 1744-1750.

BOZORGI, H. R., AZARPOUR, E. and MORADI, M. 2011. The effects of bio, mineral nitrogen fertilization and foliar Zinc spraying on yield and yield components of faba bean. World Applied Science Journal, 13(6): 1409-1414.

DIXON, R. and KAHN, D. 2004. Genetic regulation of biological nitrogen fixation. Nature Reviews Microbiology, 2: 621-631.

EVANS, J., MCNEIL, A. M., UNKOVICH, M. J., FETTELL, N. A. and HEENAN. D. P. 2001. Net nitrogen balances for cool-season grain legume crops and contributions to wheat nitrogen uptake: a review. Australian Journal of Experimental Agriculture, 41(3): 347-359.

FIGUEIREDO, M. V. B., MARTÍNEZ, C. R., BURITY, H. A. and CHANWAY. C. P. 2007. Plant growthpromoting rhizobacteria for improving nodulation and nitrogen fixation in the common bean (Phaseolus vulgaris L.). World Journal of Microbiology and Biotechnology, 24: 1187-1193.

GEETHA, V. and VARUGHESE, K. 2001. Response of vegetable cowpea to nitrogen and potassium under varying methods of irrigation. Journal of Tropical Agriculture, 39: 111-113.

GICHARU, G., GITONGA, N., BOGA, H., CHERUIYOT, R. and MAINGI, J. 2013. Effect of inoculating selected climbing bean cultivars with different rhizobia strains on nitrogen fixation. Online International Journal of Microbiological Research, 1: 25-31.

HABETE, A. and BURAKA, T. 2016. Effect of Rhizobium inoculation and nitrogen fertilization on nodulation and yield response of common bean (Phaseolus vulgaries L.) at Boloso Sore, Southern Ethiopia. Journal of Biological, Agriculture and Healt, 6(13): 72-75.

JOHN NDLOVU, T. 2015. Effect of rhizobium phaseoli inoculation and phosphorus application on nodulation, growth and yield components of two drybean (Phaseolus vulgaris L.) cultivars. Master Thesis. Faculty of Science and Agriculture (School of Agricultural and Environmental Sciences) at the University of Limpopo, South Africa.

KJELDAHL, J. Z. 1983. A new method for the determination of nitrogen in organic bodies. Anals of Chemistry, 22: 366-382.

LAMPTEY, S., AHLABOR, B. D. K., YEBOAH, S. and OSEI, D. 2014. Effect of Rhizobium inoculants and reproductive growth stages on shoot biomass and yield of soybean (Glycine max (L.) Merril.). Journal of Agricultural Science, 6: 44-54.

MARTINS, A., KIMURA, O., RIBEIRO, R. L. D. and BALDANI, J. I. 2003. Efeito da microbiolização de sementes com rizobactérias fluorescentes do gênero Pseudomonas so- bre a "murcha fusariana" do feijoeiro (Phaseolus vulgaris L.). Agronomy Journal, 37(1): 69-75.

OLIVEIRA, I. P., ARAÚJO, R. S. and DUTRA, L. G. 1996. Nutriçâo mineral e fixaçâo biológica do nitrogênio. In: ARAUJO, R. S. et al. (Eds.). Cultura do feijoeiro comum no Brasil. Piracicaba Potafos, pp. 169-221.

OTIENO, P. E. and MUTHOMI, J. W. G. N. 2009. Cheminingwa, and Nderitu J. W. Effect of rhizobia inoculation, farmyard manure and nitrogen fertilizer on growth, nodulation and yield of selected food legumes. Journal of Bilogical Science, 9(4): 326-332.

OUFDOU, K., BECHTAOUI, N., EL ALAOUI, A., BENIDIRE, L., DAOUI, K. and GÖTTFERT, M. 2016. Symbiotic Rhizobacteria for improving of the agronomic effectiveness of phosphate fertilizers. Proceeding and Engineering, 138: 325-331.

RONNER, E., FRANKE, A. C., VANLAUWEC, B., DIANDAD, M., EDEHE, E., UKEME, B., BALAF, A., HEERWAARDENA, J. and GILLER, K. E. 2016. Understanding variability in soybean yield and response to P-fertilizerand rhizobium inoculants on farmers' fields in northern Nigeria. Field Crops Reserch, 186: 133-145.

SALEHIN, F. and RAHMAN, S. 2012. Effects of zinc and nitrogen fertilizer and their application method on yield and yield components of Phaseolus vulgaris L. Agricultural Sciences, 3(1): 9-13. 
SOARES, A. L. L., PEREIRA, J. P. A. R., FERREIRA, P. A. A., VALE, H. M. M., LIMA, A. S., ANDRADE, M. J. B. and MOREIRA, F. M. S. 2006. Agronomic efficiency of selected rhizobia strains and diversity of native nodulating populations in Perdões (MG-Brazil). I, Cowpea. Revista Brasileira de Ciência do Solo, 30: 795-802.

SORATTO, R. P., PEREZ, A. A. G. and MANZATTO, N. P. 2010. Nitrogen management for common bean crop in new and established no-tillage systems. In: $19^{\text {th }}$ World Congress of Soil Science, Soil Solutions for a Changing World. 1-6 August, Brisbane, Australia.

STAJKOVIC, O., DELIC, D., JOSIC, D., KUZMANOVIC, D., RASUlIC, N. and KNEZEVICVUKCEVIC, J. 2011. Improvement of common bean growth by coinoculation with Rhizobium and plant growthpromoting bacteria. Romanian Biotechnology Letter, 16(1): 5919-5926.

TAIRO, E. V. and NDAKIDEEMI, P. A. 2013. Yields and economic benefits of soybean (Glycine max L.) as affected by Bradyrhizobium japonicum inoculation and phosphorus supplementation. American Journal of Research and Communication, 1(11): 159-172.

UYANÖZ, R. and ÜMMÜHAN, K. 2011. Effects of different salt concentrations and Rhizobium inoculation (native and Rhizobium tropici CIAT899) on growth of dry bean (Phaseolus vulgaris L.). European Journal of Soil and Biology, 47(6): 387-391.

VARGAS, M. A. T., MENDES, L. C. and HANGRIA. M. 2000. Response of field grown bean to Rhizobium inoculation and nitrogen fertilization in two cerrados soils. Fertility of Soils, 32: 228-233.

XU, B. J. and CHANG, S. K. C. 2008. Total phenolic content and antioxidant properties of eclipse lack beans (Phaseolus vulgaris L.) as affected by processing methods. Journal of Food Science, 73: 19-27.

Contact information

Peyman Sharifi: sharifi@iaurasht.ac.ir 